\title{
DANCESCAPE IN SAYAW BARONG PERFORMANCE OF BAJAU SAMA
}

\author{
Mohammed Iqbal Badaruddin ${ }^{1}$ \\ Zaimie Sahibil $^{2}$ \\ Luqman Lee ${ }^{3}$ \\ Simon Soon ${ }^{4}$
}

\begin{abstract}
${ }^{I}$ Visual Art Dept., Inst. in Advanced Studies, Faculty of Creative Arts, University of Malaya ${ }^{2}$ Visual Art Dept. Faculty of Humanity, Art and Heritage, University Malaysia Sabah (Malaysia) ${ }^{3 \& 4}$ Visual Art Dept. Faculty of Creative Arts, University of Malaya (Malaysia) iqbal688@uitm.edu.myl ; affymie@ums.edu.my ${ }^{2}$; simonsoon@um.edu.my ${ }^{3}$; luqlee@um.edu.my ${ }^{4}$ Received: 20 Februari 2021 / Accepted: 15 Mei 2021
\end{abstract}

\begin{abstract}
Sayaw barong is one of the traditional performances for the Bajau Sama ethnic in Kota Belud, Sabah. With parang barong itself as a primarily customised weapon, this symbolic performance represents the war dance in Bajau martial arts locally and used as an offensive and defensive technique (buah/jurus silat) that merges in different streams (aliran) of silat such as silat kuntau, silat sping/sprint, silat betawi, and silat Nusantara. Through participants' observation and performance ethnography, this particular style and technique encompasses the identity of Bajau Sama martial art through artistic movement as a representation that is also performed during other traditions such as wedding ceremonies, traditional healing, or funeral as their own cultural value. By referring to The Fan theory suggested by Schechner, it shows how this tradition links and connects to other elements in sacred space such as ritualization, shamanism, rites and ceremonies. This paper also discusses the use of parang barong as a material culture and how its appearance helps the efficacy of the performance. The concept of sacred-scapes, death-scapes and kinetic-scapes take shape as tangible and intangible in order to understand this particular custom and how it fits in the Bajau identity as their own art of defence traditions. It also shows the Bajau Sama belief system that creates space in ritual including initiations, customs and celebrations.
\end{abstract}

Keywords: Sayaw barong, Bajau Sama, traditional performance, art and custom. 


\section{INTRODUCTION}

This paper examines the unique and artistic style of sayaw barong by the Bajau Sama ethnic in Kota Belud, Sabah. Sayaw barong is a war dance or traditional martial art performance that is prominent within the Bajau Sama custom and tradition where it is learned and styled by a majority of local silat streams in Kota Belud.

This traditional performance is related to the cosmological values within the belief system of the Bajau Sama community and acts as an initiation phase in the martial art practices. Although the Bajau community has embraced Islam around the $14^{\text {th }}$ century, their cosmological beliefs still contain not only the existence of surgah (upper world) and narkah (under world) but also involves various dimensions or other realms where their spiritual ancestors or mangat/ embo' can be found and contacted (Bottignolo, 1995; Ibrahim et al., 2013: 2-3; M. Yakin, 2013). ${ }^{1}$

The effects of Islamization among the Bajau community in Sabah have created a process of syncretism between their ancestral beliefs and the religion conveyed by Muhammad SAW. It can be traced in the ukkil motif pattern designs on the male and female sunduk in the Bajau Kubang community located at Omadal Island, east coast of Sabah (Ibrahim et al., 2013: 27-29). Meanwhile, Amilbangsa (2006: 31) explained that the motif of jawi in the form of khat alNaskh can be found in the crafts of the Badjao-Tausug and Iranun communities at southern Philippines. This includes paper sheets in the Quran, the sunduk of Raja Baguinda and traditional pis cloth used as male headgears. ${ }^{2}$

In its traditional healing ritual known as ngalai, Saidatul Nornis (2018: 108) stated that the Bajau Sama community believes that the month of Muharam and Safar in the Islamic calendar are buan naas or unpleasant months and that any rituals or rite activities such as seeking help and blessings from the embo' should be avoided. This is because it is the 'breaktime' for the supernatural beings at their own place and that they wish not to be disturbed. However, the informant said that the practice of sayaw barong can still be performed depending on the situation or specific time such as during wedding ceremonies, martial arts training, ngelau embo' ritual, or when treating patients possessed by evil spirits or demons. The author presumes that the concept of time in the sayaw barong performance depends only on certain occasions. 
Thus, this traditional martial art performance is not only inherited from previous generations but also manifests their custom ethics, discipline, attitude and behaviour within the local community. It is a symbol of respect to the ancestors' spirits and also to avoid any disturbance by the evil spirit especially during afterlife. Furthemore, the negligence of such ritual may result in unfortunate events to their daily activities such as natural disaster, disruption in water supply, or descrease in agriculture production. The Bajau also believe that one's soul may be captured by the demon, dragged to the underworld and become a djin that dwells in the metaphysic world to serve saitan (devil).

\section{OBJECTIVE}

The main objective of this writing focuses on the philosophy of sayaw barong through the practice of Bajau martial arts in their community. It also shows how the concept of space exists through the performance. Such concept of space sees the intrinsic meaning behind the kinetic movement as a symbol of barakat (blessings) from tuhan (God) by balancing their physical and spiritual world through celebrations and traditions.

Among the artistic performance involving sayaw barong include during wedding ceremony in front of the newlywed, martial art graduation, personal use as a theraphy, pendinding (intangible shield), treating patients, or even for the purpose of bringing good fortune. This unique performance is one of the factors due to the diaspora from their previous land and their cultural value in the concept of Bajau Sama rice cultivation on the west coast of Sabah.

\section{RESEARCH METHOD}

Other than documenting the styles and techniques of sayaw barong, several in-depth interviews were conducted among Bajau parang-smiths known as panday basey and martial art experts who practise self-defence especially silat kuntau/koentaw (a silat stream in Malay Archipelago). This study also refers to the concept of performance ethnography to identify the techniques and dynamic movements in sayaw barong. It is a method proposed by Farrer (2009) who studied Malay martial arts, Seni Silat Haq Melayu and other self-defence styles. Farrer referred to the performance study suggested by Schechner (2006, 2013) on performances and restored behaviors (Hussin, 2012; Hafzan, 2013) before outlining $3 \mathrm{~A}$ and $3 \mathrm{~B}$ as a guide when conducting a research. The former refers to artistry, analysis and activitism while the latter focuses on creativity, critique and citizenship. For the purpose of conducting the in-depth interviews, 
the researchers spent significant amount of time to learn and understand the styles and techniques of sayaw barong from several martial arts practitioners especially Silat Kuntau Nakhoda Sug.

\section{Brief History of Bajau Ethnic in Sabah}

Bajau is the second largest ethnic in Sabah after Kadazandusun. This ethnic is geographically divided into two large groups located at the west cost and east cost of Sabah. Usually, Bajau Laut/Delaut or the sea gypsis, can be found along the east coast area like Sandakan, Lahad Datu, Semporna, Kunak and Tawau. Whereas, the Bajau Sama or the 'Cowboy of the East', are land settlers located at Putatan, Tuaran, Kota Belud, Kota Marudu and Kudat. Most Bajau Sama in the west coast of Sabah are farmers who dwell in the field of agriculture while few of them work as fishermen along the riverside and coastal area.

Previous studies suggested that the Bajau people are believed to originate from the province of Mindanao in southern Philippines before migrating to Palawan and the province of Sulu as a result of political instability, piracy and slavery between the $15^{\text {th }}$ and $16^{\text {th }}$ century A. D. However, there was no restriction on the movement of this community to North Borneo (Sabah) due to the existence of diplomatic relation between the sultan of Brunei and the sultan of Sulu at that time. In fact, the Tempasuk area up to Sungai Sugut is an independent administrative area and the influence of a local government head by the datus and sharifs facilitates the settlement of the Bajau community with other local ethnic groups (Buyong, 1995; Basrah Bee et al., 2015).

Following an interview with the local district informant, the researchers concluded that most of the Bajau Sama community in Kota Belud admitted that they are from Mindanao and belong to the duetro Malays. This statement is also acknowledged by Buyong (1995) and Saat (2008) who stated that the Bajau and other ethnic groups in Sabah are a community from the Malayo-Astronesian clump as their spoken language is Filipina-Farmosa from the Indonesian family.

\section{Sayaw Barong}

Sayaw is one of the performing arts practiced in the Bajau Sama self-defence. In the Hiling-Sama dialect, sayaw means war dance and it refers to strong and indirect movements and steps. It is a practice of strengthening the movement of both hands to carry traditional weapons either for striking and defending in combats and fights which later became a spiritual art practice once the particular disciple 
reaches the intermediate level. This performance of enhancement is equipped with traditional weapons such as parang (machete), karis (kris), pidah (knife), or budjak (spear). Unlike other arts and crafts, sayaw is never inherited through generations within a Bajau Sama family but rather it is acquired by undergoing trainings with a grand master depending on one's own level of understanding, expertise and handling a particular weapon.

Sayaw barong is believed to be used as an initiation process for certain rites. This process is often paired with asking for protection and blessings from mangat and embo' who are in another realm. Usually, sayaw barong is performed in a special room with a small number of audience such as during rituals like berunsai, bertitik, tinggayun, isun-isun or traditional healing like ngalai, igal dance, pagkanduli or melabuh ajung/anjung that emphasis an offering to spiritual ancestors and other beings. However, there is an exception for wedding ceremonies where sayaw barong is performed in front of the public.

According to Schechner (2013), Rappaport (1979) states that a ritual can be stylized, repeated, stereotyped and performed in a special place according to the time and date that has been selected and agreed by the custom chief and dukun (shaman). ${ }^{3}$ Schechner (2013) pointed out that although a ritual is considered an habit and routine that can be obsessed, most of the activities contain sacred or secular elements performed in public or hidden with the performers involved commonly wearing traditional clothing that comprises specific equipment and special materials. ${ }^{4}$

While the importance of a ritual according to a study by Sharifuddin Zainal et al. (2018), who referred to The Fan projected by Schechner (2013: 18) on several genres in a performance (Figure 1). This theory helped him to analyse the traditional theater performance of Melabuh Ajung and its significance to the Bajau community of the east coast of Sabah through three types of rituals namely Ajung Berasyik, Ajung Panansang and Ajung Magbuaya. In "Performance Studies: An Introduction", Schechner (2013) also presented the theory of The Web next to The Fan. According to Schechner, The Fan in performing arts is more organised and done in an orderly manner. Ritual is a term from ethology while ceremonies and celebrations focus on human habits within the group itself. However, The Web explains about systems that are more dynamic and highly dependent on their individual experiences. Each group is interconnected but it is irregular and constantly changing. Therefore, Sharifuddin referred to The Fan as it is clearer and more accurate within the subjects. 
Based on Sharifuddin's reference to the Melabuh Ajung ritual, The Fan theory is more suitable to understand the relationship between the art-making process (traditional weapon), the role of rituals, as well as ceremonies and martial arts activities (shamanism) with the purpose and function of the forged blades.

Through documentation and study on three rituals, Hanafi (2012) explains the concept of space and time in igal (dance) of the Bajau Laut community as a method of communicating with the omboh/embo' to ask for blessings and good fortune in the future. Hanafi and MCM Santamaria (2019) then developed the idea proposed by Bottignolo (1995) on how the concept of space and time can be formed into an analysis study through scapes (space).

On the other hand, MCM Santamaria (2019) attempted to understand the concept of space through the suggestion of the $X$ and $Y$ axis in some part of the house during the ritual ceremony. This includes the dancer's room, the shaman's room, the musician and the sacred spaces which are the places where the spirits are summoned to 'have' the prepared offerings. Adapted from Bottignolo (1995), this method translated the spiritual aspects or sacred spaces among the Badjao community in the Tawi-Tawi Island such as the social and religious axes within the selected space in their homes and traditional boats such as lepa-lepa, which is a place where they settled. Santamaria then developed the method by analysing the sacred space through the aspects of movement (kinetic) and music room (sound-scape) during the ritual ceremony. This concept helped Hanafi and Santamaria to study in detail other concepts of space (scape) in Bajau ritual ceremonies such as sacred room (sacred-scape), music (sound/ sonic-scape) and different types of movement (kinetic-scape). The study showed tangible and intangible meaning and interpretation when rituals are performed during a selected time, place and location. Through D.S Farrer (2006); Hussin and Baptist (2019), Appadurai explains that the concept of space has various forms according to the field of study including ethnoscapes, mediascapes, technoscapes, financescapes and ideoscapes. 


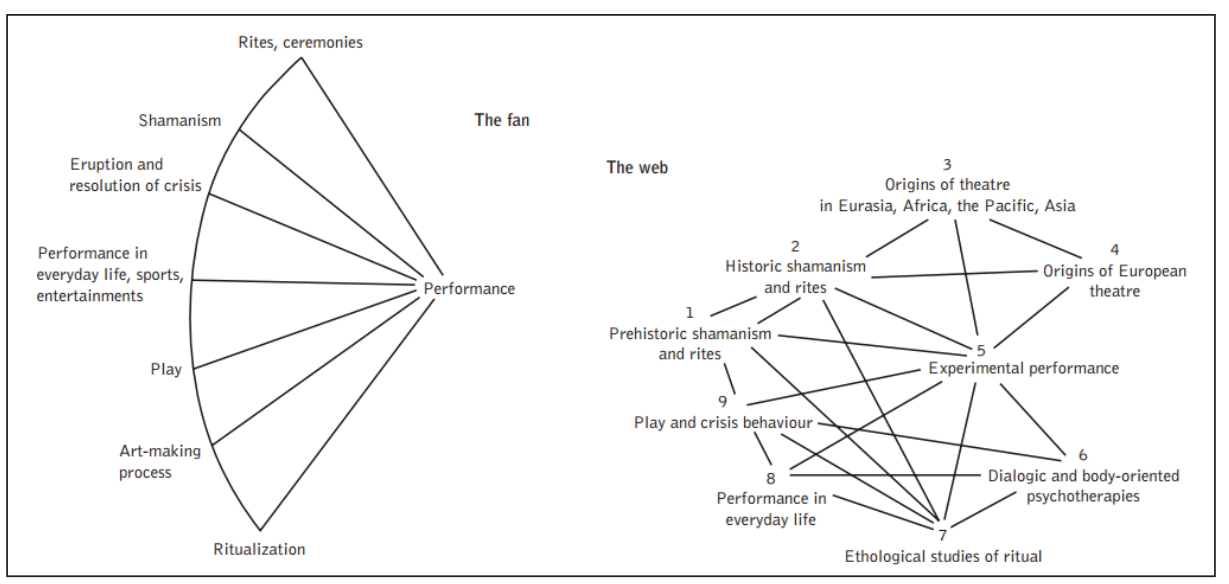

Fig. 1 The Fan (left) and The Web (right) theory suggested by Richard Schechner in The Performance Studies: An Introduction. Extracted from Performance Studies (1977).

Kilde (20:2008) states that sacred space is also associated with the local cultural areas or places. In addition to the impacts of Bajau diaspora, the later generations processed it according to the background of the settlement area to suit the religion and customs of the local community. There are also certain groups such as $d u k u n$ or bomoh who have chosen specific areas when performing worshiping or summoning rites such as cemeteries, locations of death tragedies, in the forest, or any locations that are suitable and far from the locals. Kilde explained that although a sacred space is guided by the religion itself, it is also related to the history of a particular area in the community.

The concept of death-scapes proposed by Farrer also explains that the room leads to spiritual values inherent in the practice of meditation among Malay martial arts practitioners or pesilat/mahaguru (grandmaster). The practice of asceticism involves a space in selected cemetery as a final test in completing the training in silat. In addition to this practice, a death-scapes also involves some spiritual values such as borrowing strength from the spirit of Malay warriors who were in another world/realm or animal spirit in their (Malay) mythology such as garuda (eagle), naga (dragon), pak belang (tiger), or ular (snake). Finally, the custom made parang is used as an amulet that is either inherited from the previous master or from panday basey master craft as one of the pendinding or intangible shields to protect them from any physical strike or spiritual offense from other silat practitioners. These custom-made weapons can be a tempered blade such as kris (keris), small knife, sticks, bracelets, personal rings, or martial art clothings or headgear. Farrer stated that the practices in martial art include 
the belebat performance, opening rites before silat training and asceticism at the cemetery during their (pesilat) final test. ${ }^{5}$ The three activities also involve specific dates as stated by his informant.

The statement cited by Farrer is to understand how a ritual practice in Malay martial art upholds a basic ground rule and can be modified depending on a particular pesilat to suit their own style and technique, including the concept of death-scapes that he (pesilat) uttered. Such aspect forms the identity of a martial art apprentice when he is 'outside' the training ground that structures him to be a disciplined person with a good and strong character in order to set an example to the community, especially the younger generation.

However, Kapferer and Farrer (2016: 12) stated that even though the form of performing arts that involves spiritual values such as rites, rituals, mycticisim and worshiping shows an act that reflects negative elements, it protects a person from black magic. Until now, rituals in the local community are still debated in the field of anthropology.

Meanwhile, parang barong is a traditional weapon of the Bajau community in Sabah, southern Philippines and north Sulawesi. In the Hiling-Sama dialect, barong means width. Barong's blades are made of steel and forged according to the size of the owner's arm between 14 to 15 inches. The width of its blade also follows the width of the owner's fingers between three inches. The size of a barong machete blade is wider than other machetes where the thickness of its blade is between $4 \mathrm{~mm}$ to $5 \mathrm{~mm}$. Barong's blade is shaped like a betel leaf and has a resemblance to a bolo knife. The design of barong is believed to have been copied and inherited from the Moro people of southern Philippines through barong's hilt that shares the shape of tindukbelek (eagles's head), tindukmanuk (rooster's head), sarimanuk (rooster), sarinaga (dragon) and tapakkuda (horse's hoof) including the barong's blade (Krieger, 1926, 1959; Iqbal Badaruddin, 2019: 127). ${ }^{6}$ The parang barong symbolises bravery, struggle and heroism where the Bajau will usually carry it as men's traditional attire during the Sultan of Sulu and Sultan of Brunei era in north Borneo (Sabah). 

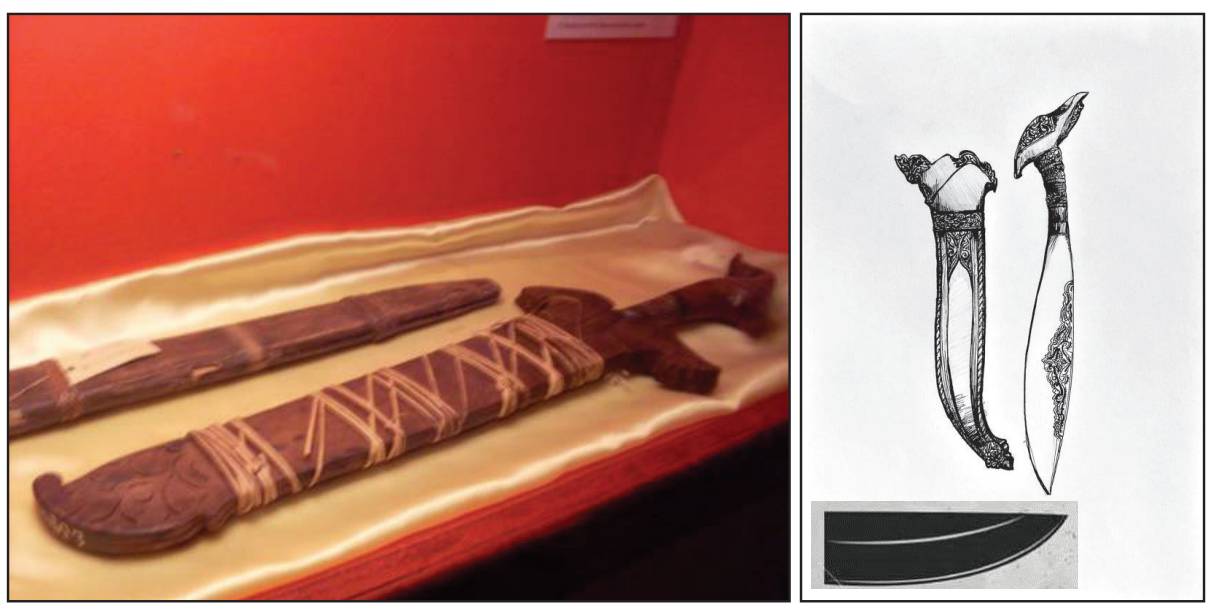

Fig. 2 (Left) One example of Barong/Barong machete design on display at Sabah State Museum. Permanent collection of Sabah State Museum (with permission). (Right): Painter's illustration of a barong/barong machete design. Blade type straight back.

\section{Performance of Enhancement in Sayaw Barong}

After performing the final ritual which is known as the closing rites for custom made weapon, the panday basey then will wrap the weapon and deliver to the particular individu who have made the reservation. The panday basey will do the rite alone in his own sacred room at midnight during the lunar moon of the Islamic calendar. According to the informant, the best time to perform the ritual is before the Subuh prayer between 12.00am to 4.00am because there is a thin line between the physical and spiritual world. This last process is to ask for blessing from the embo' or mangat and to ensure that the weapon is always in good condition with its new owner. The panday basey will also inform the spirits that the parang does not belong to him anymore and that he will not take any responsibility for any wrongdoings in the future. This is an initial rite between the panday basey and the weapon before delivering it to its new owner. Before performing a sayaw, the panday basey will sit cross legged facing the Qiblat. Although it is not compulsory to face the Qiblat, the tradition has been inherited from the previous master (guru). It acts not only as a syncretism between culture and religion but also as a barakat (blessed) to the tuhan (god) since the spirit of duwata, which is also a good spirit from the Bajau ancestor, also embraces Him (Allah) as The Almighty. He then plays the sayaw by holding the blade and sprinkles on a smoke and at the sametime reciting selected $d u^{\prime} a$ and mantra (spells). This particular rite is only practiced in certain panday basey family and only passed down from the guru to his apprentice. 


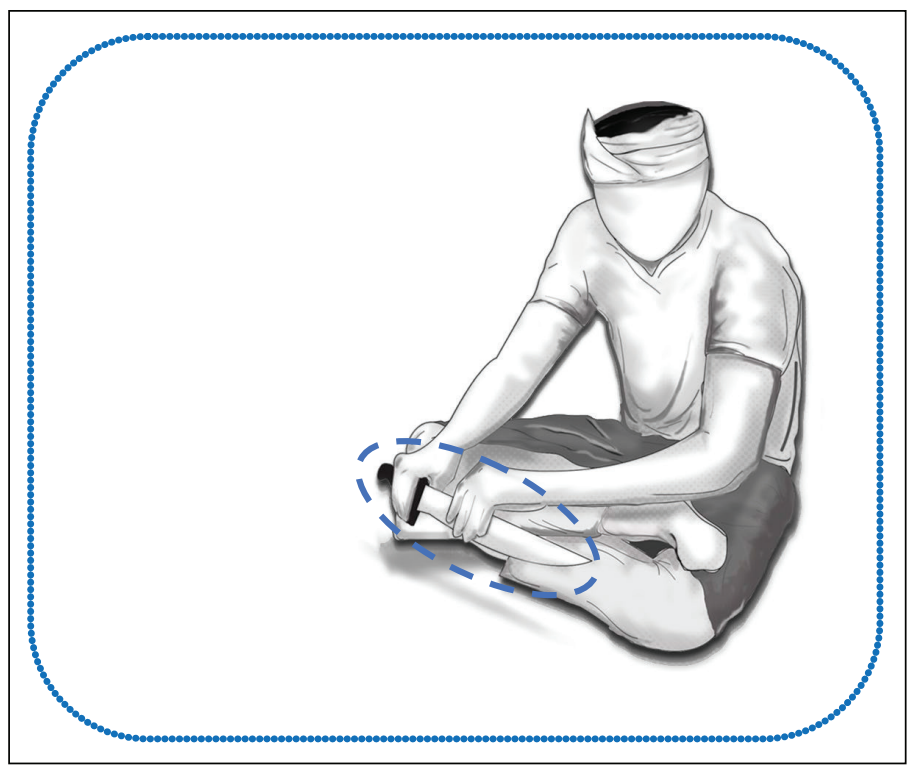

Fig. 3 Illustration of a panday basey performing a rite as an initiation before handing over the weapon to its owner

\section{Wedding Ceremony}

Usually, sayaw barong is performed in front of a wedding couple and the audiences in standing position either individually or in a group. The performance is played by their own family members from both sides either with or without betitik traditional music.

Table 1 Sayaw barong performance in wedding ceremony

\begin{tabular}{|l|l|}
\hline Analysis of Sayaw Barong in Wedding Ceremony \\
\hline Kinetic space & $\begin{array}{l}\text { Moderate and relaxing (to entertain), grasping hulu (hilt) } \\
\text { parang, pointing front and back. } \\
\text { Others: Static and dynamic movements. Parallel and } \\
\text { diagonal steps, front and back steps, half circle turns. }\end{array}$ \\
\hline
\end{tabular}




\begin{tabular}{|l|l|}
\hline Time duration & Flexible; 2-3 minutes \\
\hline Meaning behind the ritual & $\begin{array}{l}\text { Creating 'X' and full circle back-to-back in front of the } \\
\text { wedding couple but did not pointing the downstream of } \\
\text { parang (mata parang). } \\
\text { The 'X' movement represent 'J' (lam+alif) which mean } \\
\text { Laa Ilaa haaillallah (There is no God other than Allah } \\
\text { SWT). } \\
\text { Circle represent 'r' (mim) which refer to Prophet } \\
\text { Muhammad SAW. } \\
\text { Along with (or without) betitik (traditional music } \\
\text { performance), praying/reciting du'a and mantra asking } \\
\text { a bless from embo'/omboh/umboh (ancestral spirit) and } \\
\text { to protect the marriage from any intruders (physical/ } \\
\text { spiritual). Ex: black magic, evil curse (santau/sihir). }\end{array}$ \\
\hline
\end{tabular}

\section{Opening Rites in Buka Gelanggang}

Before a martial art training session, the particular disciple or the apprentice will perform sayaw barong in front of his/her master and other students. This performance usually applies as an opening rite in the training space and it is not necessarily applied for new martial art schools only.

Table 2 Sayaw barong performance in wedding ceremony

\begin{tabular}{|l|l|}
\hline Analysis of Sayaw Barong in Opening Rites for Martial Art Training \\
\hline Kinetic space & $\begin{array}{l}\text { Aggressive and fast, holding hulu parang/ parang's blade or } \\
\text { together with taguban (parang's case). } \\
\text { Others: Static and dynamic movements. Parallel and diagonal } \\
\text { steps, front and reverse steps, side and front kick, jumping, } \\
\text { chopping, slashing and stabbing. }\end{array}$ \\
\hline
\end{tabular}




\begin{tabular}{|l|l|}
\hline Time duration & Night, before training start; within 2 minutes \\
\hline Meaning behind the ritual & $\begin{array}{l}\text { Reciting bismillah hirrohman nirrohhim (in the name of Allah, } \\
\text { The Most Merciful and Most Gracious). } \\
\text { Giving salam and bending knee. Twisting parang downstream } \\
\text { at each } 4 \text { directions by creating 'S' ('S' + 's'; vertical \& } \\
\text { horizontal) in parallel steps. } \\
\text { As an opening gateway for the warrior spirit. This spirit } \\
\text { can provide definite strenght the young guru (s) by } \\
\text { creating pendinding (spiritual/intangible shield) that used } \\
\text { in preventing evil spirit/force (saitan/jin/gimbaran) that } \\
\text { likely want to enthral other students/disciples. The symbol } \\
\text { 'S' (movement) referred to sarinaga (dragon) which is } \\
\text { believed represent embo' in the shape of naga that bring strength } \\
\text { and protection. Sarinaga was referred and extracted from } \\
\text { traditional local motif that can be found on their woodcarving's } \\
\text { pattern or cloths. For example, Bajau's headgear, traditional } \\
\text { boat, tombstone or sacred houses (Baradas, 1968; Pang N.Y, } \\
1990 ; \text { Amilbangsa, 2005 \& Badaruddin M. I et al., 2019). It } \\
\text { also showed a good example to the others who learn martial } \\
\text { art not to asking help (power/magic) from evil spirits from } \\
\text { another dimension. }\end{array}$ \\
\hline
\end{tabular}

\section{Sayaw Rites in Funeral}

According to the informant, the ritual is only applicable among parang-smiths or panday basey community who have passed away. It is an initiation process for the parang-smith masters to begin their afterlife journey without any disturbance from the evil spirits. Other than martial art experts, it is also practiced among the panday basey community.

Table 3 Sayaw barong performance in funeral rites

\begin{tabular}{|l|l|}
\hline Analysis of Sayaw Barong in Ritual Tarik Basey \\
\hline Kinetic space & $\begin{array}{l}\text { Slowly and calm, grasping the parang without its casing. } \\
\text { Others: Static movements. Only moving and twisting the } \\
\text { parang's blade on the death body (panday basey). }\end{array}$ \\
\hline
\end{tabular}




\begin{tabular}{|l|l|}
\hline Time duration & Night before burial ceremony; Dependable \\
\hline Meaning behind the ritual & $\begin{array}{l}\text { Reciting bismillah hirrohman nirrohhim (in the name of Allah, } \\
\text { The Most Merciful and Most Gracious) and specific mantra } \\
\text { emphasizing "don't die in kufr (infidel)". Then blow some air } \\
\text { and making horizontal movement repeatedly on the death body } \\
\text { from the head to the leg gently without take out the cloth or } \\
\text { touching the body. } \\
\text { Once finished, the parang's blade will be wipe with his (guru) } \\
\text { bare hands which later washed with mixed water (coconut, lime, } \\
\text { water that used for forging process). } \\
\text { - Wipe out or absorb small pieces of metal and other supernatural } \\
\text { beings to make sure the death body is in good hygiene and } \\
\text { 'clean'(sacred) before entering the other world (akhirat). } \\
\text { Protecting the death body from evil beings/dark spirits such as } \\
\text { saitan, jin, balan-balan etc). }\end{array}$ \\
\hline
\end{tabular}

\section{Sayaw Barong in Traditional Healing}

Like other ethnics that practise traditional healing, most of the ngalai processes are done by a dukun (shaman). Nevertheless, martial art gurus with knowledge in healing will also be asked by the family members to perform sayaw barong as an option in treating patients possessed by evil spirits.

Table 4 Sayaw barong in traditional healing

\begin{tabular}{|l|l|}
\hline Analysis of Sayaw Barong in Traditional Healing \\
\hline Kinetic space & $\begin{array}{l}\text { Moderate and concerned, holding the parang together with its } \\
\text { casing. } \\
\text { Others: Static movements. Pointing and creating intangible } \\
\text { jawi font. }\end{array}$ \\
\hline
\end{tabular}




\begin{tabular}{|l|l|}
\hline Time duration & Night; Dependable \\
\hline Meaning behind the ritual & $\begin{array}{l}\text { - Reciting bismillah hirrohman nirrohhim (in the name of Allah, } \\
\text { The Most Merciful and Most Gracious), placing parang in } \\
\text { vertical position facing the patient. } \\
\text { Creating 'ن' (nun) movement while pointing the parang's } \\
\text { downstream to patient's body and reciting a healing mantra. } \\
\text { Creating clockwise circle above the head while the other hand } \\
\text { pointing to the patient before slowly blowing a small amount } \\
\text { of air to the patient and into a bowl of water. } \\
\text { Lastly the guru dipped his bare hand into a bowl of water and } \\
\text { wipe the patient's face. } \\
\text { - The 'ن' (nun) movement represent Nur which means light } \\
\text { (cahaya). The clockwise circle is a symbol in creating an } \\
\text { intangible shield (pendinding) to make sure there will be no } \\
\text { interruption and disturbance from other evil curse/spirits and in } \\
\text { the future. } \\
\text { It is believed that there was a good spiritual force after reciting } \\
\text { du'a and mantra in a bowl of water. The water can wipe out } \\
\text { unconscious view that was enfolded from evil spirit. }\end{array}$ \\
\hline
\end{tabular}

\section{DISCUSSION AND RESULT}

There are different styles and technique in sayaw barong that was performed by different people with strong characters, depend on certain occasion for wedding ceremonies, traditional healing or funeral. Each of these individuals can be a panday basey, martial art guru (master) or dukun (shaman) in that particular community which plays their own roles in social hierarcy and performed with their own customade traditional weapon which is belief a place where supernatural beings such as duwata or ruwata dwell. ${ }^{7}$ However, this performance create spiritual space by communicating with their ancestors to ask for blessings and to avoid from any unfortunate event in the future. This concept of space/scape involved physical and spiritual aspect where the performer first shows off their own style of martial art dance in that particular location before slowly tranced themselves into spiritual world and communicating with spirits to ask for barakat.

Although it is a performance of enchantments where it shows a quality in sacred expression, it also built a level of confidence to the performers and bring hope to the audience in facing a challenging yet rough world outside their community. However, in search for salvation, it's not only represents the ritual or religious experience, but also fulfil their personal aspirations in sacredness throughout celebrations, healths and offering to the mangat or embo' in the realm world. 
Each of the performance have different philosophy in each rite which based on experiences and observation. While there was a sign through communicating to the realm world, the syncretism between Islam and Bajau culture shows the balance through beliefs and daily activities that created their own identity from other ethnic in west coast of Sabah. According to Farrer (2009: 225-227), other than occulturation in mystical practice, it also showed the way of life in divination and revelation that created vulnerability and multiple strength of each pesilat's self-defense.

For example, the opening rites in martial art training, a student of the perguruan or martial art school which is the guru's apprentice will learn to understand the sacredness of the performance through his own creator's (tuhan) ability and how the force was created and existed. While revelation focus on that particular apprentice in gaining physical and spiritual strength to discipline himself as a Muslim and martial art practitioner after the training was completed and appointed as young guru. Once he/she understand their own potential, the sayaw performance is just a secondary practice and not necessarily apply in creating an intangible space.

Another example is the practice of cultural performance in wedding ceremonies that not only sayaw barong but also include other dancespace in martial art with different styles of silat movements and technique along with multiple performance art such as traditional songs, dances and games (Farrer, 2009: 93). This was another way in neutralizing the sayaw performance rites in Islamic traditions and cultural value by entertaining the raja sehari and both family members that attended the ceremony. ${ }^{8}$ Usually the performance art can also be found in other Muslim weddings in Malaysia, Indonesia, Borneo and Sulu Archipelago with different types of styles to show the continuous tradition and heritage.

The practice of sayaw and combination of doa (pray) in Islam and spells have existed as early as $14^{\text {th }}$ century where the Bajau and other ethnic in southern Philippines embraced Islam during Spaniard times and after the migration of the Bajaus to North Borneo, the assimilation and acculturation with other local ethnic neutralized between traditions and religion (Baradas, 1960 \& Ibrahim et al., 2013). This practice was passed down from the previous generations and slowly merged between Islamic traditions and animism beliefs which how the sayaw barong and other art performance applied in their own doa by worshipping God almighty and ancestor's spirits (Halina Sendera, 2013). 


\section{CONCLUSION}

The sayaw barong is one of the war dance or martial art performance practiced by the Bajau as a symbol of strength and ritualization emphasizing cosmological background that link with social events such as the anti-war during colonization in North Borneo (Sabah) and southern Philippines.

Today, this unique performance only appears in certain occasion traditionally in their very own culture value. However, it was practiced only in close group and selected individuals although it can be performed in front of the audience as a repertoire and entertainment that played along with traditional music as part of the cultural tourism locally and internationally.

The other important points are the presence of Islamic tradition through doa, spells and depiction of myth and shadows of the warrior in creating an intangible space as an access to the metaphysic world to ask for barakat both from tuhan and embo'. Except the use of spells for magic and shamanism to seek advantage from mangat, this tradition can still be practice and celebrate in modified ways in time before pass down to young and emergence students. The Bajaus are deeply tied with embo' and mangat because they believe in sacred power and will try to seek for it in multiple ways specially in cultic activities.

\section{NOTA}

${ }^{1}$ Surgah: upperworld; heaven, narkah: underworld; hell.

2 Ukkil motif: A traditional carved design or drawing styles.

Sunduk: Traditional Bajau tombstone design placed on a graveyard.

${ }^{3}$ Roy A. Rappaport (1979), Ecology: Meaning and Religion - The Obvious Aspect of Ritual dlm. Schechner (2013), Performance Studies ( $3^{\text {rd }}$ ed.), Routledge Taylor \& Francis Group, NY, USA.

${ }^{4}$ Ibid.

${ }^{5}$ Belebat: A dynamic step in martial art performances.

${ }^{6}$ Moro people was a term coined by the Spaniards during their colonialization era in southern Philippines between $14^{\text {th }}-17^{\text {th }}$ century. Moro people include the Samal/Samar, Tausug/Suluk, Iranun, Visaya, Badjau and other local ethnics.

${ }^{7}$ Duwata: A good spirit of ancentors in Bajau and are blessed from tuhan (God).

Ruwata: An evil spirit that tag along with devils and jin (genie).

${ }^{8}$ Raja sehari: Malay muslim wedding couple seated in front of the audience on pelamin, a small stage decorated with traditional cloths.

\section{REFERENCES}

Amilbangsa Ligaya, F. (2006). Ukkil: Visual Arts of The Sulu Archipelago. Quezon City: Ateneo de Manila Press.

Badaruddin M.I., Soon S., Lee L., Sahibil Z., \& A. Tarmizi M.S.H. (2019). Bird as a subject in wood carving motifs: An observation on Bajau traditional weapons. Borneo Research Journal. 
Baradas David, B. (1968). Some implication of the Okir motif in Lanao and Sulu art. Journal of Critical Perspective on Asia, Asian Center.

Basrah Bee, B., A. Rahim M. Saffie., M. Radzi M. Shaukhi \& Ali I. (2015). Sharif Osman dalam konteks sejarah Borneo suatu penilaian semula, figura dan fakta perjuangan di Sabah. Kota Kinabalu: ABIM Negeri Sabah.

Bottignolo, B. (1995). Celebrations with the sun: An overview of religious phenomena among the Badjaos. Quezon City: Ateneo de Manila University Press.

Buyong, J. (1995). Islam dalam sejarah dan kebudayaan suku kaum di Sabah. Warta Masyarakat, Utusan Borneo, 2 September 1995, pp. 10.

Farrer, D.S. (2006). Deathscapes of the Malay martial artist. Social Analysis, Vol. 50, Issue Berghahn Journals.

Farrer, D.S. (2009). Shadows of The Prophet: Martial arts and mysticism, Muslim and global societies series, Vol. 2. http://www.springer.com/series/7863.

Farrer, D.S. (2016). War magic: Religion, sorcery, and performance (pp. 12-13). New York: Berghahn Book.

Farrer, D. S. (2018). Chapter 10: Performance Ethnography. https://www.academia. edu/37506220/Performance_Ethnography, pp. 147-148.

Halina Sendera, M. Y. (2013). Cosmology and world-view among the Bajau: The supernatural beliefs and cultural evolution. Mediterranean Journal of Social Sciences, 4(9), 184-194.

Hamza, Z. Hafzan. (2013). Igal: The traditional performing arts of the Bajau Laut in Semporna, Sabah. Master thesis (performance art). (unpublish). Institute of Postgraduate, University of Malaya, Kuala Lumpur.

Hussin H. (2012). Balancing the spiritual and physical worlds memory, responsibility and survival in the rituals of the Sama Dilaut (Bajau Laut) in Sitangkai, Tawi-Tawi/ Southern Philippines and Semporna, Sabah/Malaysia, Oceans of Sound Sama Dilaut Performing Arts. Abels B., Grant M. Josephine, \& Waczkat A. (Eds.). Göttingen Studies in Musicology, (Vol. 3). Amsterdam, Netherland.

Hussin, H. \& Baptist, John, J. (2019). Scaping the Bajau through rituals and celebrations in maritime of Malaysia. Borneo Research Journal, Special Issue.

Ibrahim, I., Aminullah. M. Azareen., Jusilin H., Bebit. M. Pu'ad \& Sahibil Z. (2013). Warisan seni dan budaya: Masyarakat kepulauan pesisir Sabah. Kota Kinabalu: Penerbit Universiti Malaysia Sabah.

Kilde, J. Halgren. (2008). Sacred power, sacred space: An introduction to Christian architecture \& worship. Oxford: Oxford University Press.

Marinsah, S.A., \& Ramli. M.A. (2017). Sinkretisme dalam adat masyarakat Bajau di Sabah. International Journal of Islamic Thought, 12, 83-93.

MCM, Santamaria. (2019). Cosmology and the construction of space in three Sama Bajau rituals. Borneo Research Journal, Special Issues, 26-41.

Pang Ngun Yue. (1990). Tales of The Suluk Headgear, Sabah Times-19 Ogos 1990, Sabah State Museum Archive, Kota Kinabalu, Sabah.

Saat, G. (2008). Implikasi politik Melayuisme Sama-Bajau di Malaysia. Sari, 26, 63-70.

Sharifuddin, Z., Mohd Kipli, A. R., \& Mohammad Azirul, I. (2018). 'Melabuh Ajung': Signifikasi Kepercayaan Kosmologi Dalam Pembentukan Identiti Teater Tradisional Etnik Pantai Timur Sabah: 'Melabuh Ajung': Signification of Cosmological Belief in Developing Traditional Theatre Identity of Sabah'S Eastcoast. Jurnal Gendang Alam (GA). 


\section{List Of Informants}

i. $\quad$ Tuan Hj. Ebin bin Adim (1940-2020), Panday Basey Master, Kampung Siasai Kumpang, Tukang Ulung (Craftmens) Awards 2012, National Craft Day 2012, Perbadanan Kemajuan Kraftangan Malaysia (PKKM).

ii. Tuan Arin bin Usop (78), Panday Basey Master (Bajau Sama), Kampung Siasai Jaya, Kota Belud, Sabah.

iii. Tuan Jamawid bin Soh (51), Panday Basey Master, Kampung Siasai Jaya, Master Craftmen (Iron-smith in Traditional Weapon) 2012, National Craft Day 2012, PKKM.

iv. Tuan Bakah bin Jab (71), Panday Basey Master (Bajau Sama), Kampung Siasai Tamu, Kota Belud, Sabah.

v. Sam bin Kenang, panday basey Kampung Siasai Kumpang, Kota Belud, Sabah.

vi. En. Chiptoh bin Paratoh, Deputy Director, Craft Development Admission, Perbadanan Kemajuan Kraftangan (PKKM) Malaysia.

vii. En. Abdul Rahman bin Omar, Craft Enterpreneurship Admission, Perbadanan Kemajuan Kraftangan (PKKM) Malaysia.

viii. En. Said bin Pawel (37), Panday Basey Master (Bajau Sama), Kampung Siasai Jaya, National Craft Day 2019, PKKM.

ix. Hj. Majad Ab. Halim (59), Panday Basey Master (Bajau Sama), National Craft Day 2019, PKKM.

x. Assoc. Prof. Dr. Hanafi Hussin, Senior Lecturer, Department of Southeast Asia Studies, Faculty of Art and Social Science, University of Malaya.

xi. Assoc. Prof. Dr. Ismail Ibrahim, Senior Lecturer, Faculty of Technology, Art and Heritage, Universiti Malaysia Sabah.

xii. Dr. Muhammad Shaiful Anuar bin Yusof, Senior Lecturer, Academy of Linguistic Studies, Universiti Teknologi MARA, Kelantan.

xiii. En. Mohd Sallehuddin bin Maslin, pengusaha parang Bajau, Keningau, Sabah.

xiv. En. Mohamad Hafizi bin Ab. Aziz (Awang Lutong), iron-smith (traditional weapon), Kuala Lumpur.

xv. Saharizan bin Sulaiman, iron-smith and martial arts guru, Kuala Lumpur.

xvi. Tuan Razali bin Mohd Thani, master crafts, Kuala Lumpur.

xvii. Tuan Zainol Hj. Hairuddin, master crafts, Kuala Lumpur.

xviii. Guru Ahmad Riza bin Hashim, Grand Master Persatuan Seni Silat Kuntau Nakhoda Sug dan traditional weapon collector, Taman Desa Keramat, Ampang. Kuala Lumpur.

xix. En. Mohd Shahril bin Mohd Yusof, senior member, Persatuan Seni Silat Kuntau Nakhoda Sug, Pandan Indah, Ampang, Kuala Lumpur.

xx. En. Arif Hafizi bin Radzi, researcher and traditional weapon collector, Ampang, Kuala Lumpur. 